\title{
Legal framework of the water sector in Vietnam: achievements and challenges
}

\author{
Khung pháp lý về tài nguyên nuớc ở Việt Nam: thành tưu và thử thách \\ Policy paper
}

Nguyen, Thi Phuong Loan*

Center for Development Research, University of Bonn, Walter-Flex-Str. 3, 53113 Bonn, Germany

\begin{abstract}
Since 1986 and especially during the early 90s, environmental protection has become a constitutional principle in Vietnam as regulated by Articles 17 and 29 of the 1992 Constitution. The first Law on Environmental Protection, passed by the National Assembly on December 27, 1993 created a foundation for environmental legislation becoming an important field in Vietnam's legal system. In the following, Vietnam enacted its very first Law on Water Resources (No. 08/1998/QH10) in January 1999 aiming to provide a foundational framework for managing the water sector in Vietnam. In recent years, the legislative framework on water resources management has further developed. Important water-related regulations on the guidance and implementation of the Law on Water Resources have been issued and often amended to meet the requirements of the country's development, and its international integration. To date, Vietnam's legislation on the water sector consists of a complex system of legal documents issued by different state agencies. Though legislation of water sector management in Vietnam has greatly improved during the last decade, it has obviously not yet come to full fruition. Hence, the paper intends to provide an overview of achievements as well as problems and conflicting issues within Vietnam's current water sector management legislation.
\end{abstract}

Kể tù năm 1986, đặc biệt là nhũng năm đầu của thập kỷ 90, bảo vệ môi trương đã trở thành nguyên tắc hiến định (được quy định tại Điều 17 và 29 Hiến pháp 1992). Luật Bảo vệ môi truờng đầu tiên đuợc Quốc họi thông qua ngày 27 tháng 12 năm 1993 đã đặt nền móng cho việc hình thành hệ thống pháp luật về môi truòng ở Việt Nam. Tiếp theo đó, ngày 20 tháng 05 năm 1998, Quốc hội nước Cộng hòa xã hội Việt Nam khóa X, kỳ họp thứ 3 đã thông qua văn bản luật đầu tiên về tài nguyên nuớc - Luật Tài nguyên nuớc số 08/1998/QH10 hình thành một nền tảng pháp lý cho hệ thống pháp luật bảo vệ nguồn tài nguyên nước ở Việt Nam. Trong nhũng năm gần đây, hầu hết các văn bản duới luật quan trong và cần thiết cho việc huoóng dẫn thi hành Luật Tài nguyên nuớc đã được ban hành và không ngùng được sứa đổi, bổ sung nhằm đáp ứng nhu cầu phát triển và hộ nhập quốc tế của đất nước trong nhiều lĩnh vực khác nhau. Tuy nhiên, khung pháp lý hiện hành về tài nguyên nuớc ở Việt Nam bao gồm một hệ thống các văn bản quy phạm pháp luật khá phưc tạp, nhiều tầng nấc, được ban hành bởi nhiều co quan có thẩm quyền khác nhau. Mặc dù hệ thống pháp luật về tài nguyên nước đã được liên tục sưa đổi, bổ sung và hoàn thiện trong suốt một thập kỷ qua, nhung rõ ràng vẫn chura thục sự đi vào cuộc sống. Bài viết duới đây đề cập chủ yến đến một số các thành tưu cũng nhu nhũng vấn đề mâu thuẫn hiện tại của pháp luật bảo vệ nguồn tài nguyên nuoóc ở Việt Nam.

Keywords: Mekong Delta; water resources management; state management; legal framework

\section{Introduction}

In order to ensure the sustainable exploitation and use of water resources Vietnam has started to elaborate a legal framework of the water sector during recent years. The
Law on Water Resources No. 08/1998/QH10 issued on May 20, 1998, has created the foundation for the legal system on water resource protection in Vietnam. After ten years of implementation, this law represents a major step forward on integrated water resources management. Required secondary regulations covering most water-related 
protection issues have been adopted and frequently amended to meet the requirements of the country's development, and its international integration in different aspects. However, due to the pressures of industrialization and modernization, water resources have not been developed in a sustainable and integrated manner; socioeconomic development has not been aligned with the water sources capacity to meet the point of view of the "National strategy on water resources to 2020" approved by the Prime Minister's Decision (No. 81/2006/QD-TTg). The escalating exploitation and use of water resources as well as the discharging of untreated wastewater into water sources have caused serious levels of water pollution, degradation and exhaustion; the use of water sources is no longer harmonized with the interests of local communities. Although the legislation has greatly improved during the last decade, it has obviously not yet had the desired effect. The current legal system for the protection of water resources in Vietnam therefore seems to be insufficient. The main aim of the paper is thus to clarify and determine the need for a new comprehensive Law on Water Resources. In detail, this paper consists of the following chapters: The first chapter provides a brief overview on the position and role of the legislation on the water sector in Vietnam. Chapter two consists of a comprehensive overview of the key regulations for water resources management in Vietnam, while the third chapter is dedicated to the state management system of Vietnam's water sector. Finally, the achievements and main challenges of the current legislation on water sector are identified in the final chapter.

\section{Position and role of legislation on the water sector}

In January 1999, Vietnam enacted its very first Law on Water Resources No. 08/1998/QH10, which was adopted in May 1998 to provide a foundational framework for managing the water sector. The law outlined state management, exploitation and utilization, the protection of water resources and sanctions against violations, as well as international relations in water resources management. To guide the Law on Water Resources' implementation, Decree No. 179/1999/ND-CP was promulgated by the Government on December 30, 1999, and prescribed in detail state management, exploitation and utilization, the protection of water resources, especially relating to the discharge of wastewater into water sources, and the granting of permit(s) related to water resources, as well as the prevention of, combat against and overcoming of harmful effects caused by water. These two legal documents created a legal basis for the management of the water sector in Vietnam. Accordingly, water resources are under the ownership of the entire population and uniformly managed by the state. All organizations and individuals have the right to exploit and use water resources to meet their daily life and production demands. Besides, they are also obligated to protect and develop water resources in a sustainable manner, as well as to prevent against and mitigate for any harm caused by water.

In addition, important related laws and ordinances have been developed to meet the requirements of the country's development and its international integration in different issues regarding environmental protection, in particular water resources protection: the Ordinance on Natural Resources Tax (amended) 1998, Ordinance on Exploitation and Protection of Irrigation Works 2001, the Law on Land 2003, the Law on Fisheries 2003, the Law on Inland Waterway Navigation 2004, the Law on Dykes 2006, and especially the Law on Environmental Protection 2005 (which replaced the Law on Environmental Protection 1993). These legal documents have an inseparable relationship with the legislation on the water sector (see chapter 2).

Apart from the legal groundwork for managing the water sector (the Law on Water Resources and the Decree 179/CP) and respective laws/ordinances, important secondary regulations have been developed to provide further provisions for protecting the country's water resources. In recent years, over 300 legal documents required to implement the Law on Water Resources have been developed as secondary regulations to protect and sustainably develop water resources from a range of different legal viewpoints. Overviews of the secondary regulations on exploitation and utilization, the protection of water resources and sanctions against violations - as well as dispute settlement within the water sector - are provided in-depth in chapter 2. An overview of the position and key dimensions of water sector legislation in Vietnam is provided in chart 1 (see Annex).

\section{Key regulations for the water re- sources management in Vietnam}

Vietnam's legislation on the water sector consists of a complex system of legal documents issued by different state agencies. Like other legal fields, the groundwork of the legislation for the water sector is many-faceted. Numerous water-related legal documents are specified by general laws and ordinances. Other regulations are systematized and prescribed by specific secondary regulations.

Above all, as specified in Article 29 of the 1992 Constitution * (amended), the task to protect the environment is a constitutional obligation: “...all state agencies, armed forces units, economic organizations, social organizations and individuals have to observe state regulations on the radical utilization of natural resources and protecting the environment. Any acts resulting in the depletion and destruction of the environment are strictly prohibited". This regulation created the constitutional foundation for communicating to all subjects in charge of environmental development the obligation to protect the environment. Besides, the 1992 Constitution (amended) also stipulated through Article 17 that "...land, forest, rivers and lakes, water resources, underground natural resources, resources in the territorial water, etc. fall under the ownership of all people", exerting a deep influence on the legal

\footnotetext{
* The fundamental rights of Vietnamese citizens including their civil, political, economic, and social rights are recognized in the 1992 Constitution (amended), which is applied as the basic regulation in the Vietnam's legal system.
} 
status of subjects in charge of the environment. These constitutional regulations on environmental protection caused a further impact on the contents of other legal documents related to the environment, which had to comply with the 1992 Constitution (amended).

Apart from the constitutional obligation, numerous important laws and ordinances have been developed to meet the requirements of the country's development and its international integration in different issues ${ }^{\dagger}$. Based on the Law on the Promulgation of Legal Documents No. 17/2008/QH12 (hereafter called the LPLDs 2008), laws (luât) are promulgated by the National Assembly, addressing fundamental issues in the following fields: economics, society, national defence and security, finance, money, the budget, tax, ethnicity, religion, culture, education, health, science and technology, the environment, external relations, the organization and functioning of state apparatus, the civil service, public officials and civil servants, and the rights and obligations of citizens. Ordinances (nghi quyêt) issued by the Standing Committee of the National Assembly contain regulations on issues suggested by the National Assembly. After a certain period of implementation, these issues are proposed for development into laws for the National Assembly's consideration.

Accordingly, the Law on Water Resources (Luật Tài nguyên nước) No. 08/1998/QH10 (hereafter called the LWR), passed by the National Assembly at the $10^{\text {th }}$ legislature, $3^{\text {rd }}$ session on May 20, 1998 stipulates the management, protection, development, and utilization of water resources, as well as the control and mitigation of any adverse consequences caused by water. Water resources stipulated in this law refer to surface water, rainwater, groundwater and seawater within the territory of the Socialist Republic of Vietnam. In legal terms, "water resources" refers to various forms of natural or man-made water accumulations that can be exploited and used rivers, streams, canals, ditches, sea, lakes, lagoons, ponds, aquifers, drains, ice, snow and other forms of water accumulation. Depending on quality and features, there are different requirements on the management and use of water resources. The LWR divides these into specific groups: (1) "Surface water" occurring on the surface of the mainland or on islands; (2) "Groundwater" occurring

\footnotetext{
$\dagger$ Based on the Law on the Promulgation of Legal Documents No. 17/2008/QH12, legal documents are those issued or jointly issued by state organizations in compliance with this law or the Law on the Promulgation of Legal Documents of the People's Councils and People's Committees. They consist of common rules of conduct and are compulsory. Their implementation is guaranteed by the Government to regulate social relations (Article 1). Accordingly, the legal documents of Vietnam are divided into laws/regulations and secondary regulations. Laws/ordinances are legal documents passed by the National Assembly, the highest constitutional body of the Socialist Republic of Vietnam - the only body vested with constitutional and legislative powers. Laws/Ordinances shall be applied as regulations with the supreme legal force of the legal system in Vietnam. Should other legal documents not be promulgated in accordance with the Constitution, laws and resolutions, they cannot be considered as legal documents (Article 146 of the 1992 Constitution; Article 1, Para.2 of the LPLDs 2008). For further information about the Vietnam's legal system, please refer to Nguyen, Loan 2010a: 2 - 12.
}

in aquifers underground; (3) "Domestic water" used for cooking, drinking and sanitary purposes; (4) "Domestic water source" supplied as domestic water or water, which can be economically treated to meet the quality requirements of Vietnam's standards for clean water; and (5) "International water sources" flowing from Vietnamese territory to other countries, from the territory of another country into Vietnam, or occurring on the border between Vietnam and a neighbouring country.

In particular, the LWR consists of ten chapters with 75 Articles, and has been in force since January 01, 1999. Apart from the general provisions (ownership, subject and scope of application, legal term explanations, etc.), the LWR provides provisions on protecting water resources (chapter II); the rights and obligations to exploit and use water resources (chapter III); the prevention, control and mitigation of the consequences of flooding, inundation and other adverse effects caused by water (chapter IV); the exploitation and protection of hydraulic works (chapter $\mathrm{V}$ ), as well as international relations in respect of water resources (chapter VI); state management on water resources (chapter VII); the duties and authority of specific inspectorates for water resources (chapter VIII); violation settlement (chapter IX); and, finally, implementation provisions (chapter X).

In addition, related regulations on the obligation to protect water resources have been drawn up for other different key laws/ordinances as follows:

The Ordinance on Natural Resources Tax (Pháp lệnh Thuế Tài nguyên sưa đổi) (No. 05/1998/PL-UBTVQH10) was promulgated by the Standing Committee of the National Assembly on April 16, 1998, and replaced the Ordinance on Natural Resource Tax issued on March 30, 1990. Taking effect since June 01, 1998, this ordinance aims at contributing to the protection, exploitation and use of natural resources in an economic, rational and effective manner, as well as protecting the environment and ensuring revenue sources for the state budget.

The Ordinance on the Exploitation and Protection of Irrigation Works (Pháp lệnh khai thác và bảo vệ công trinh thüy lơi) (No. 32/2001/PL-UBTVQH10) was passed by the Standing Committee of the National Assembly on April 04, 2001, and replaced the ordinance on the exploitation and protection of irrigation works adopted on August 31, 1994. This ordinance applies to irrigation works that have been built and already put into operation. Accordingly, the exploitation and protection of irrigation works is related to dykes, flood and storm prevention works and hydroelectric works, as well as water supply and drainage works for urban areas.

The Law on Land (Luật Đất đai) (No. 13/2003/QH11) was issued on November 26, 2003 and replaced the first Law on Land from 1993. This law prescribes the authorities and responsibilities of the state that represents the people ownership of land; performs the united management over land, land use management, and rights and obligations of land users. Accordingly, one of the key principles of land use is ensuring the economical and efficient use of environmental resources, as well as pro- 
tecting the environment. Additionally, any plans drawn up for land use must ensure that natural resources are rationally used and exploited and the environment protected and developed in a sustainable manner.

The Law on Fisheries (Luật Thủy sản) (No. 17/2003/QH11 dated November 26, 2003) was adopted on November 26, 2003. This Law applies to the fishery activities of Vietnamese organizations and individuals, foreign organizations and individuals on land, islands, internal water, territorial sea, exclusive economic zones, and the continental shelf of the Socialist Republic of Vietnam.

The Law on Inland Waterway Navigation (Luật Giao thông đưòng thủy nội địa) (No. 23/2004/QH11) was passed on June 15, 2004. This Law applies to organizations and individuals involved in navigable inland waterways activities, providing provisions for navigable inland waterways activities and conditions to ensure safety for navigable inland waterways infrastructures, vessels and people participating in navigable inland waterways and transport.

The Law on Environmental Protection (Luật Bảo vệ môi truò̀ng) (No. 52/2005/QH11) - hereafter called 'LEP 2005' - was passed by the National Assembly in response to changes in the country's development requirements. It replaced the first Law on Environmental Protection in 1993 (LEP, 1993). Previously, the scope of the LEP 1993 covered purely environmental protection activities including maintaining clear and clean air, improving the environment, ensuring ecological balance, preventing and overcoming any adverse effects caused by the environment, and determining the rational and economical exploitation and utilization of natural resources. Today, the LEP 2005 provides not only environmental protection activities, but also policies, measures and resources for protecting the environment, as well as regulations on the rights and obligations necessary to protect the environment for state agencies, organizations, households and individuals, overseas Vietnamese, and foreign organizations and individuals carrying out activities in the Socialist Republic of Vietnam. The chart 2 shall provide an overview of the key laws and ordinances promulgated since 1993, all of which have an inseparable relationship with legislation on the water sector in Vietnam (see Annex).

Apart from the legal groundwork for managing the water sector (the LWR and related key laws/ordinances as mentioned above), various important secondary regulations (văn bản duói luật) have also been developed to protect water resources in different areas, as well as to deal with violations against laws and ordinances. An overview of secondary regulations on the management of the water sector in Vietnam shall be presented based on the key

\footnotetext{
* Secondary regulations are issued by administrative and judicia organizations, which provide detailed guidelines on the implementation of laws and ordinances. However, secondary regulations are legal documents of a lower rank than laws/ordinances relating to the legal force in the legal documents' hierarchy. Executive organizations, at national level as well as local level, also have power to promulgate legal documents.
}

subjects addressed by the current LWR (exploitation and utilization, protection, violations and sanction, and dispute settlement).

\section{Regulations on the exploitation and utilization of water resources}

According to the current Law on Water Resources, water resources are under the entire population's ownership and uniformly managed by the state. All organizations and individuals have to the right to exploit and use water resources to meet their daily life and production demands, and also have the responsibility to protect and develop water resources in a sustainable manner and prevent and mitigate harm caused by water in accordance with the provisions of law. However, their legitimate rights and interests in exploiting and utilizing water resources should be protected by the state.

In detail, as regulated by Article 9 of Decree No. 179/1999/ND-CP providing guidelines for the implementation of the Law on Water Resources, organizations and individuals that exploit and use water resources for daily life, agriculture, industrial production, mining, and electric power generation have to apply for permits from competent state agencies. Conditions for granting such permits must be based on current legislation on water resources and other relevant forms of legislation. Permits for the exploitation and use of surface water are valid for twenty years. Permits for the exploitation and use of groundwater are valid for fifteen years. Competent state agencies to grant such permits shall decide their extension, but each extension must not exceed ten years.

\section{Regulations on the protection of water resources}

In recent years, Vietnam has built up and implemented various programmes and strategies on water resource protection and development, such as the "National Target Program for Clean Water and Environmental Hygiene in Rural Areas" approved by Decision of the Prime Minister No. 237/1998/QD-TTg dated December 03, 1998 and "Orientation for the Development of Urban Drainage in Vietnam up to the year 2020" ratified by Decision of the Prime Minister No. 35/1999/QD-TTg. The long-term objective up to 2020 - to substantially improve drainage is aimed at protecting and upgrading the urban environment, doing away with the usual waterlogging during the rainy season in the urban centers. Each urban centre shall have its own wastewater drainage system, with the appropriate technology to ensure hygienic disposal of excess water. Specific objectives of the programs ${ }^{\S}$ on national strategy on environmental protection are to put an end to the exploration, exploitation and use of water resources and the discharge of wastewater into water sources without the permission of competent agencies - controlling the pollution of water sources and ending the use of toxic

\footnotetext{
$\S$ "National Strategy on Environmental Protection till 2010 and orientation towards 2020" was adapted by Decision of the Prime Minister No. 256/2003/QD-TTg dated December 02, 2003; "National Strategy on Water Resources to 2020" approved by the Prime Minister's Decision No. 81/2006/QD-TTg on April, 14, 2006.
} 
chemicals in industrial and agricultural production and aquaculture. In addition, polluted water decreases biodiversity, so the strategy will also ensure that the exploitation of water does not exceed the exploitation limits for rivers, exploitable deposits or for water-bearing beds.

Organizations and individuals that own investment projects subject to an EIA report (Environmental Impact Assessment report) shall carry out by themselves EIA reports or use a qualified consultancy service or organization (as specified in Article 14 of the LEP 2005) to do this job. EIA reports have a strict content format (Circular No. 05/2008/TT-BTNMT ${ }^{* *}$ provides details for the implementation of strategic environmental assessments, the environmental impact assessment and environmental protection commitments; Government's Decree No. 80/2006/ND-CP of August 09, 2006 on detailing and guiding the implementation of a number of articles of the LEP 2005; Government's Decree No. 21/2008/ND-CP of February 28, 2008 on amending and supplementing a number of articles of the Government's Decree No. 80/2006/ND-CP).

Besides, based on the current Law on Water Resources, organizations and individuals exploiting and using water resources have to apply for permits, except the cases regulated by Clause 2, Article 24 of the LWR.

Issuance of permits ${ }^{\dagger \dagger}$ for water resources exploitation, extraction and utilization and wastewater discharge into water sources is further regulated by the Government's Decree No. 149/2004/ND-CP of July 27, 2004 and MONRE's Circular No. 02/2005/TT-BTNMT issued on June 24, 2005. Accordingly, exploration, exploitation, inventory and use of water resources must comply with the planning approved by competent state agencies. In addition, permits for exploitation, use of water resources and discharge of wastewater into water sources must stipulate all environmental protection conditions. Exploitation and use of water resources, as well as discharge of wastewater into water sources must comply with environmental, water resources protection permits' contents granted by competent state agencies. Organizations and individuals shall have to comply with environmental, water resources protection requirements during inventory, exploration, exploitation and use of water sources. Wastes from production, business, service, construction, transport activities, exploitation of riverbed minerals and garbage from households living on the rivers must be controlled

\footnotetext{
** It replaced the Circular No. 08/2006/TT-BTNMT of September 08,2006 on providing details for the implementation of strategic environmental assessments, the environmental impact assessment

$\dagger^{\dagger}$ Permits of exploration, extraction and utilization of water resources and of wastewater discharge into water sources include: (1) Groundwater exploration permit; (2) Groundwater extraction and utilization permit; (3) Surface water exploitation and utilization permit; and (4) Wastewater discharge permit. (Government's Decree No. 149/2004/ND-CP of July 27, 2004; MONRE's Circular No. 02/2005/TT-BTNMT issued on June 24, 2005).
}

and treated to meet the environmental protection requirements before being discharged into rivers.

A wastewater discharge permit shall be issued initially for duration of 10 years from the date of its approval and periodically renewed to extend the permit for up to 05 years. The renewal of wastewater discharge permit shall comply with the provisions in Article 5 of the Decree No. 149/2004/ND-CP; particularly, licensing of wastewater discharge into water sources must be based on following foundations: (1) National Technical Specifications on the Environment ${ }^{+1}$; (2) Assimilative capacity of water sources $^{\S \S}$; and (3) Sanitary protection zones defined by competent state agencies. Process and procedure on licensing of; as well as extending and/or renewing granted permit on wastewater discharge is specified in Article 22 and 23 of the Decree No. 149/2004/ND-CP. Regime of collection, remittance, management and use, evaluation charge and administrative fee for grating permits for exploration, exploitation and use of water resources, as well as permit on discharge of wastewater are regulated by Decision No. 59/2006/QD-BTC issued on October 25, 2006 by the Ministry of Finance.

Regarding groundwater, based on the Decision No. 05/2003/QD-BTNMT of September 04, 2003 issued by Ministry of Natural Resources and the Environment for licensing groundwater exploration, exploitation and drilling practice, "exploration of groundwater" means the combined use of various geological survey methods to appraise and determine deposits and the quality of groundwater, and to forecast the environmental impacts on a given area, which may be caused by water exploitation, aiming to serve the designing of water exploitation projects with set outputs. Competent state agencies in charge of granting, extending, adjusting and revoking

$\$$ Currently, the list of National Technical Specifications on the Environment (Quy chuẩn kỹ thuật quốc gia về môi truờng QCVN) according to the Decision No. 16/2008/QD-BTNMT issued on December 31, 2008 by the Minister of the Ministry of Natural Resources and the Environment; including:

- QCVN 08/2008/BTNMT - National Technical Regulation on Surface Water Quality;

- QCVN 09/2008/BTNMT - National Technical Regulation on Ground Water Quality;

- QCVN 10/2008/BTNMT - National Technical Regulation on Coastal Water Quality;

- QCVN 11/2008/BTNMT - National Technical Regulation on Aquatic Products Processing Wastewater;

- QCVN 12/2008/BTNMT - National Technical Regulation on Pulp and Paper Mill Wastewater;

- QCVN 13/2008/BTNMT - National Technical Regulation on Textile Industry Wastewater;

- QCVN 14/2008/BTNMT - National Technical Regulation on Domestic Wastewater;

- QCVN 15/2008/BTNMT - National Technical Regulation on Pesticide Residues in the Soils

$\S \S$ As regulated by current Circular No. 02/2009/TT-BTNMT of March 19, 2009 issued by MONRE on evaluation of the ability of water sources to receive wastewater, "capable of receiving wastewater" is the ability of water source to receive additional load of certain pollutions which ensures that the concentration of water polluted substances still does not exceed the limit values defined by the regulations and standards on water quality for the purposes of the receiving water. 
such permits are the Ministry of Natural Resources and the Environment and People's Committees (provincial level). Cases of groundwater exploration and exploitation not subject to permission are regulated by Article 7 of Decision No. 05/2003/QD-BTNMT. Further regulations on licensing groundwater exploration, exploitation and drilling practices are provided in Decision No. 17/2006/QD-BTNMT of October 12, 2006 on the granting of practice permits for groundwater drilling, Decision No. 13/2007/QD-BTNMT of September 04, 2007 on groundwater resources investigation and assessment, and Decision No. 15/2008/QD-BTNMT of December 31, 2008 on the protection of groundwater resources.

Based on the Prime Minister's Decision No. 277/2006/QD-TTg dated December 11, 2006 on approval of the National Target Program for rural water supply and sanitation period 2006-2010, Decision No. 51/2008/QD-BNN was issued by the Ministry of Agriculture and Rural Development on April 14, 2008, which provides regulation on issuance of the monitoring and evaluation indicator set for the clean rural water supply and environmental sanitation. An overview of the current key regulations on the protection of the water sector in Vietnam, as well as an important number of regulations dealing with disaster preventions are provided in chart 3 (see Annex).

\section{Regulations on violations and sanctions}

Any act by an individual or organization, whether deliberate or not, which violates the principles of the regulations on the state management of water resources, shall be subject to administrative sanctions (Government's Decree No. 34/2005/ND-CP of March 17, 2005 on sanctions against administrative violations of water resources management regulations, and the Circular No. 05/2005/TTBTNMT of July 22, 2005 on guiding the implementation of the Decree No. 34/2005/ND-CP). Accordingly, administrative violations of water resource management regulations subject to this case consist of: (1) Violations of water resource protection regulations; (2) Violations on regulations covering water resources exploration, exploitation and utilization, as well as the discharge of wastewater into water resources; (3) Violations of regulations concerning the collection, management, dissemination and use of water resources data and/or information (in more detail see Nguyen, 2010a). An overview of the key regulations on sanctions against administrative violations in the environmental field in general and particularly in the water sector in Vietnam is provided in chart 4 (see Annex).

\section{Regulations on environmental dispute settlement}

According to Article 62 of the Law on Water Resources, disputes within the water sector shall be settled as follows: (1) The People's Committees of communes shall have the responsibility for dispute mediation; (2) Agen$\operatorname{cies}^{* * *}$ with authority to issue certain types of water re-

\footnotetext{
*** As regulated by the Government's Decree No. 149/2004/NDCP, Decree No. 13/2008/ND-CP, and MONRE's Decision No. 216/2009/QD-BTNMT, agencies with the authority to issue
}

sources permits shall have the responsibility of settling claims as well as complaints arising from the implementation of those types of permits; (3) Should the complainant disagree with the complaint settlement decision of the Ministry of Natural Resources and the Environment, Head of the Department of Water Resources Management, or President of provincial-level People's Committees, he/she may, within 30 days from the date of expiration of the settlement time limit defined in Article 43 of the Law on Complaints and Denunciations (the same 30-day limit applies if the complaint has not yet been settled), initiate an administrative lawsuit before the provincial-level People's Court $^{\dagger \dagger \dagger}$ (Article 39, 46 of the Law on Complaints and Denunciations 1998, amended in 2004 and 2005). An overview of the current disputes settlement system in environmental fields in Vietnam shall be provided in chart 5 (see Annex).

\section{State management of Vietnam's wa- ter sector}

According to the current legislation on water sector management, the Government shall carry out unified state management in respect to water resources. The Ministry of Natural Resources and the Environment shall be responsible to the Government for implementing state management in respect to water resources. Ministries, ministerial-level agencies and agencies attached to the Government shall implement state management in respect to water resources according to the authority and assignments given by the Government. At local levels, People's Committees (provincial level) shall be responsible for state management in respect to water resources within their localities. The organizational system, tasks and authorities of the competent state management agencies in charge of water resources under the MONRE and People's Committees (at all levels) shall be stipulated by the Government.

Based on the Law on Organization of the Government (Luật Tổ chức Chính phủ) No. 32/2001/QH10 of December 25, 2001, the Government, which is composed of the Prime Minister, Deputy Prime Ministers, Ministers and Heads of ministerial-level agencies, is the executive body of the National Assembly and the highest administrative state body of Vietnam (Article 109, 110 of the 1992 Constitution; Article 3 of the Law on Organization of the Government). In respect to water resources management, the Government carries out unified state management (Article 4, 58 of the LWR).

The Ministry of Natural Resources and the Environment (Bộ Tài nguyên và Môi trường), hereafter called

permits and to license the exploration, extraction, exploitation and utilization of water resources, as well as wastewater discharge into water resources are: the Ministry of Natural Resources and the Environment, the Department of Water Resources Management, People's Committees of provinces, and other agencies in charge of the state management of water resources.

it For further information about the Vietnam's court system, please refer to Nguyen, 2010a 
'MONRE', was established in 2002 in accordance with the Government's Decree No. 91/2002/ND-CP, which was recently amended by the Government's Decree No. 25/2008/ND-CP of March 04, 2008. Accordingly, MONRE is a governmental agency, performing the state management of land, water resources and mineral resources as well as geology, environment, meteorology and hydrology, metrology and cartography, sea and inlands.

The National Water Resources Council (Hội đồng Quốc gia về Tài nguyên nước), hereafter called the 'NWRC', was established in 2000 by the Government to advice on important decisions on water resources management. It may also assist MONRE and other ministries to share water resources information and to better coordinate the activities of international donors (according to the Law on Water Resources, the Decision of the Prime Minister No. 67/2000/QD-TTg of June 15, 2000).

The Department of Water Resources Management (Cuc Quản lý Tài nguyên nước), hereafter called the 'DWRM', was established in 2003 in accordance with the Decision of MORNE No. 600/2003/QD-BTNMT of May 08, 2003, which was recently amended by Decision No. 1035/QDBTNMT of May 19, 2008 on stipulating the functions, tasks, powers and organizational structure of the Department of Water Resources Management. Accordingly, the DWRM is an organization under MONRE, which provides assistance to the Minister of MONRE in implementing the nationwide state management of water resources.

In addition, the Appraisal Councils (Hội đồng Thẩm dịnh) (as stipulated by the Decision 13/2006/QDBTNMT), Inspectorates (Thanh tra Tài nguyên Môi truòng) (as stipulated by the Government's Decree No. 35/2009/ND-CP), the Centre for Water Resources Planning and Investigation - CWRPI (Trung tâm Quy hoạch và Điều tra Tài nguyên nước) (as stipulated by the Decision No. 1027/QD-BTNMT of May 16, 2008).

Indirectly, the Ministry of Agriculture and Rural Development (Bộ Nông nghiệp và Phát triển nông thôn), hereafter called 'MARD', the Ministry of Industry (Bộ Công thuong), Ministry of Health (Bộ $Y$ tế), the Ministry of Construction (Bộ Xây dụng), and the Ministry of Transport (Bộ Giao thông Vận tải), with their specialized departments for environmental protection, also have inseparable roles in the state management of water resources. MARD, for instance, is still responsible for agriculture, forestry, salt-making, irrigation, fisheries management, as well as dykes, flood and storm management, and rural water supply, even though its responsibility in the field of water resources management was transferred to MONRE in $2002^{\text {\#t }}$.

\footnotetext{
$4+$ Although the establishment of MONRE was regulated by the Government decrees in 2002, MARD was supposed to keep its functions with regard to rural development and public service delivery in the water sector, but several gaps and unclarities remained. For instance, the important point of infrastructural planning and effective decision-making power in that matter, which was not specified, turned out to be a crucial issue, longlasting inter-ministerial conflict (Molle and Hoanh, 2008; Waibel, 2010). Since 2008, number of MONRE's functions has
}

Regulation on specialized organizations and sections of environmental protection in state agencies and state enterprises is specified in the Government's Decree No. 81/2007/ND-CP of May 23, 2007. Accordingly, the Department of Environment is established at the following ministries: Ministry of Industry, Ministry of Agriculture and Rural Development, Ministry of Health, Ministry of Construction, and Ministry of Transport, in order to assist each minister from the relevant ministries mentioned above by giving advice and submitting to the minister, for issuance and implementation, legal documents, programmes, proposals and projects on environmental protection in the assigned sectors and areas. For other ministries and ministerial-level agencies where there already exists a Department of Science and Technology, these should be renamed as the Department of Science, Technology and Environment, in order to advise and submit to the ministers and heads of the above agencies legal documents, programmes, plans, projects and proposals on science, technology and environmental protection in the assigned sectors and areas. The Ministry of Public Security will investigate violations of the legislation on environmental protection. The organization and operation of 'environment police' are decided by the Minister of Public Security. On February 06, 2009, the Ministry of Public Security, together with the MONRE, issued the Joint Circular No. 02/2009/TTLT-BCA-BTNMT, guiding the cooperative relationship between the two ministries in preventing and combating violations against the legislation on environmental protection.

At local levels, Departments of Natural Resources and the Environment (hereafter called 'DONREs') are specialized organizations under People's Committees (provincial level), which assist the People's Committees to implement their state management tasks on natural resources and the environment, especially on water resources. Offices of Natural Resources and Environment that are under the People's Committees at district level shall be accountable for state management of the environment, water resources, and mineral resources, as well as land, sea and island issues. Besides, rural water supply is managed by the Departments of Agriculture and Rural Development (hereinafter referred to as DARDs) at provincial level (under supervision of MARD). It shall assist the People's Committees in implementing their state management tasks on agriculture, forestry, aquiculture, irrigation and rural development; prevention and control flood, inundation; and safety of agricultural, forest and aquiculture products. Regulation on functions, duties, authorities and structural organization of DARDs at local levels is further regulated by the Joint Circular of MARD and Ministry of Interior Affairs No. 61/2008/TTLT-BNNBNV of May 15, 2008. At the commune level, civil servants in charge of land and construction issues (under supervision of DONRE) shall be responsible for communal affairs of land and environment management, as well as

increased according to the Government decrees (No. 25/2008/ND-CP), but not all functions were taken from MARD. Among the new tasks and responsibilities of MONRE, environmental protection including climate change can be considered as key and with regard to water, the building and management of water resources observation network represents a new and huge challenge (Waibel, 2010). 
mediation of environmental disputes (stipulated by the Joint Circular No. 03/2008/TTLT-BTNMT-BNV of July 15,2008 providing regulations on functions, tasks, competences and organizational structures of agencies specialized on natural resources and environment of People's Committees of all levels).

On river basin management, the Government has recently issued Decree No. 120/2008/ND-CP of December 01, 2008. Its main aim is to protect the water environment, cope with water-based environmental incidents, regulate and distribute water resources, etc. As a guide, major river basins in the Vietnamese context consist of the Red River (sông Hồng) and the Thai Binh, Bang Giang, Ky Cung, $\mathrm{Ma}, \mathrm{Ca}, \mathrm{Vu}$ Gia, Thu Bon, Ba, Dong Nai, and Mekong River Basins. An inter-provincial river basin is stipulated as a river basin located on more than two provinces or cities under central government (Article 6, Para. 2). Based on a suggestion made by MONRE, Major River Basin Commissions (Ủy ban Luu vục sông lón) were established by the Prime Minister to supervise and coordinate the operations of ministries and local-level agencies involved in the implementation of river basin planning, as well as the exploitation, use and development of water resources (Article 30, Para.1 \& Para. 4a). Presidents of Inter-provincial river basin Commissions (Ủy ban Luu vục sông liên tỉnh) are Chairmen of People's Committees (provincial-level), with a two-year term (Article 30, Para. 3, Para. 4b). River Basin Offices (for major river basins and inter-provincial river basins) are set by MONRE to assist River Basin Commissions in implementing their tasks (Article 31). The main departments of MONRE and MARD (at national and local levels) as well as their key management functions are summarized in charts 6,7 , and 8 (see Annex).

\section{Achievements and main challenges}

It is evident that Vietnam has started to set up a framework of regulations to ensure the sustainable use, protection and development of the environment in general, and water resources in particular. The main aim of this legal framework shall serve the development of water resources in a sustainable manner, ensuring the efficient exploitation and use of water resources, and encouraging the protection and development of water resources in an integrated manner and for multiple purposes. Further, the legal framework aims to enhance the effectiveness and efficiency of state management of water resources, raising the responsibilities of private organizations/enterprises and individuals in the protection, exploitation and use of water resources, as well as the prevention, mitigation and remedying of consequences and harm caused by water.

In recent years, policies and institutional systems on water resource management have been developed and improved systematically. Besides, over more than 300 legal documents required to implement the LWR have been developed as secondary regulations to protect and sustainably develop water resources from a range of different legal viewpoints. The task of protecting the water sector in Vietnam has changed positively and, as a consequence, the awareness of water resource protection has grown considerably. At sub-national levels, legal documents related to water resource management and issued by competent state agencies have been developed in recent years. These myriad documents have, basically, created a rather comprehensive legal system for the state management of water sector protection, and raised the awareness of local people and enterprises on water resource protection and development. However, in the face of the pressures caused by industrialization and modernization, as well as the comprehensive movement of globalization and international integration, the current LWR has revealed its limitations and insufficiency. Contradictions with other related laws and secondary regulations have bared themselves in the implementation process (in more detail see Nguyen, 2010a). Though legislation of water sector management in Vietnam has greatly improved during the last decade, it has obviously not yet come to full fruition. The current legal system for the protection of water resources in Vietnam therefore seems insufficient. The proof is that, in fact, most of the surface, ground and coastal waters of Vietnam are polluted, with no current sign of abating. Water pollution, for instance, is still not yet under control (in more detail see Nguyen, Loan: 2010b). Rivers, reservoirs, water-bearing beds and submerged areas are seriously polluted, degraded and exhausted, such examples of which are: Nhue - Day River Basins, Cau River, Dong Nai (Saigon) River, Huong River, and Hau (Can Tho City) River. Especially in large cities and industrial zones, problems with the exploitation, exploration and use of water resources and the discharge of wastewater into water sources without permission still occur and remain unaddressed. Many water sources in Vietnam are dying due to the discharge of toxic chemicals from industrial and agricultural production and aquaculture, which has polluted the water sources and decreased biodiversity. Furthermore, there is increasing evidence of the pollution of surface, ground and coastal waters. Downstream sections of major rivers reveal poor water quality, while lakes and canals in urban areas are almost becoming sewage sinks. Rivers in Vietnam's urban areas, especially major cities, are seriously polluted by untreated industrial wastewater, which is a main source of water pollution. Regarding discharging wastewater for instance, according to MONRE, there are about 4,000 enterprises discharging wastewater, of which 439 are classed as 'serious' and are required to adapt cleaner technologies and treatment of their wastewater, otherwise they will be reallocated or closed. Industrial and other types of pollution add to human waste from a growing number if people. Around seventy industrial parks have been developed, and with more than 1,000 hospitals nationwide some one million cubic metres of untreated wastewater is discharged from these sources alone every day (MONRE: 2003, 22). Besides, according to the Department of Water Resources Management, the licensing of wastewater discharge into water sources is still limited in quantity. Up to this point, only 5,000 water resource permits have been issued, among which are only 400 permits on wastewater discharge into water sources (gain ca. 8\%) (DWRM: 15.05.2009). Obviously, the number of licenses given out is quite far from the needs. At local levels, the licensing of water resources continues being fraught with difficulties. 
The main cause behind the incomprehensiveness and insufficiency of the water-related legal framework in Vietnam is the lack of a united and stable legal system; conflicts and contradictions between laws, ordinances and secondary regulations still persist. Due to the fact that the Vietnamese legal system is generally complex, with varied legal documents ordered on many levels and adopted by different state authorities, the current legal framework for the water sector is thus complicated with overlapping and contradictory regulations. Regarding legal enforcement, in certain fields, regulations on the water sector are dispersed and scattered in many legal documents with identical contents, but with different hierarchies and in total contradiction of one another in many instances. The development and promulgation of legal documents must ensure the constitutionality, legality and consistence of legal documents in the legal system (Article 3 of the Law on the Promulgation of Legal Documents 2008). The current problem, though, is that the legislation lacks a general regulation on dealing with unfeasible, overlapping and unjustified water sector regulations with other related regulations (such as Law on Environmental Protection 2005, Law on Fisheries 2003, Law on Minerals 2006 (amended in 2005), Law on Inland Waterway Navigation 2004, etc.), thus causing difficulties in cases where such overlapping and contradictions have occurred. For many local state agencies in charge of water resources management, it is hard to find the "selected regulation" to deal with such cases in the implementation process. In addition, the lack of specific guiding regulations issued at national level also causes difficulties in implementation at local levels (in more detail see Nguyen, Loan 2010b). Many localities experience trouble when dealing with new situations. Regarding the drilling of wells, for instance, there is still a lack of specific guiding regulation (of national level) on filling up unused wells; regulation on guiding procures on filling up of wells; regulation on sanction against violation of legislation on groundwater protection; etc. Further, the current sanction forms are no longer suitable for specific violations against water sector regulations. For instance, fines for administrative violations against water sector legislation are not fair in many cases. Thus, it has not yet proved its worth. Seemingly most of the organizations and individuals who have violated the legislation would rather pay fines than invest their capital in the installation of environmentally friendly systems.

Concerning the improvement of water resources management capacity, Vietnam still has not attained consistency and coordination in designing and enforcing policies, laws, standards and norms in the domain of water resource to achieve more sustainability in the water sector. The state management system of water sector has not proved its worth in formulating and ensuring its effectiveness in a coordinated manner (in more detail see Nguyen, Loan: 2010a). The functions and tasks of state management agencies with a stake in water resources management is still not clearly separated from water service delivery like the operation and maintenance of water works for exploitation and use of water resources and water service supplies, only to mention one example. Thus, a revision of the Law on Water Resources is probably needed to definitely transfer decision-making power over planning to MONRE. This option would be consistent with the policy of separating the management of natural resources from its exploitation and use (Waibel 2010, Cong 2007).

Above all, regarding the right to complain, denunciate, and initiate lawsuits against acts/ decisions issued by administrative agencies, based on the Law on Water Resources (Article 22, para.4, Article 69), organizations and individuals have the rights to complain, denunciate, and initiate lawsuits against acts/ decisions issued by administrative agencies infringing upon their rights of exploitation and utilization of water resources and other legitimate interests. However, in many secondary regulations on water source protection, as well as current regulations on the wastewater management, the organizations and individuals merely shall have the right to complain and denunciate. But what is about the right to initiate lawsuits to the courts? And which state agencies should be responsible for such cases where the regulations are unclear, is still open. Obviously, the right to initiate lawsuits against decisions/acts issued by administrative agencies has been remained unused. In Can Tho City, for instance, the People's Court has not yet exercised their newly competence of dispute settlement on environmental field. Regarding disputes on water sector, there are only small cases within communal domain in which the civil servants in charge of land and construction issues are responsible for the dispute mediation according to the Joint Circular No. 03/2008/TTLT-BTNMT-BNV (Interview with the DONRE of Can Tho City: 23.03.2009, and interview with the Department of Justice of Can Tho City: 23.03.2009).

\section{Conclusion}

In order to deal with the above-mentioned problems and difficulties and to enhance water resources protection and water supply meeting the demands of socio-economic development, environmental protection and sustainable development in a period rapid of industrialization, modernization and international integration, Vietnam needs a completely new comprehensive Law on Water Resources. A draft of the Law on Water Resources (as amended) should be well prepared by the Ministry of Natural Resources and the Environment. Interestingly, the Law on Water Resources (as amended) has been noticed by pervious Legislative Programs, but so far has not been adapted yet. However, it is "still" on the list of laws to be amended by the 2010 Legislative Programme. According to the Legislative Program of 2010, approved by the Resolution of the National Assembly on July 17, 2009, along with other water-related Laws (such as the Law on Irrigation Works, Law on Protection of Maritime Environment, Law on Minerals (amended), etc.), the Law on Water Resources (as amended) shall be submitted to the Government at the National Assembly in 2010 for further appraisal. In order to allow this legal framework to fully unfold, the forthcoming regulations implementing this new Law on Water Resources must be minimized, avoiding incomprehensible regulations. Furthermore, the opinions of related organizations, individuals and international/national/ local experts must be carefully collected, and transparency in legal issues must be improved. Public hearings and participation in the legislative process must 
be conducted and implemented according to current law provisions. Above all, the forthcoming Law on Water Resources should be rewritten to enshrine a new division of roles between the two key ministries for water resources management (MARD and MONRE). The main aim of such a legal framework shall serve the sustainable development of water resources, ensuring their efficient exploration, exploitation and utilization, and encouraging the protection and development of water resources in an integrated manner and for multiple purposes now and in the future.

\section{Acknowledgement}

This paper draws on an in-depth study on the legal framework of the water sector in Vietnam prepared for the Center for Development Research (ZEF) in context of the WISDOM Project (Water-related Information System for the Sustainable Development of the Mekong Delta, Vietnam - http://www.wisdom.caf.dlr.de/).

\section{References}

[1] Cong, N.C. (2007). River Basin Management: Who are responsible? Thesis prepared at training course on state management functions. Vietnam National Academy of Public Administration (NAPA), Ministry of Home Affairs (in Vietnamese)

[2] DWRM (15/05/2009). Cả nước cấp được hơn 400 giấy phép xả thải vào nguồn nước (www.nwrc.ciren.vn)
[3] Molle, F., Chu, T.H. (2008). Implementing Integrated River Basin Management: Lessons from the Red River Basin, Vietnam. M-Power Working Paper, IDR, M-Power and IWMI

[4] MONRE (2003). Vietnam Environment Monitor of 2003 - Water (Báo cáo diễn biến môi trường Việt Nam 2003 - Môi trường nước)

[5] Nguyen, T.P.L. (2010). "Khung Pháp lý về Tài Nguyên Nước ở Việt Nam”. Can Tho University Publisher. Can Tho City, Vietnam

[6] Nguyen, T.P.L. (2010). "Legal Framework of the Water Sector in Vietnam". Can Tho University Publisher. Can Tho City, Vietnam

[7] Nguyen, T.P.L. (2010a). Legal Framework of Water Sector in Vietnam. ZEF Working Paper No. 52, Center for Development Research. University of Bonn, Bonn

[8] Nguyen, T.P.L. (2010b). Problems of Law Enforcement in Vietnam: The Case of Wastewater Management in Can Tho City. ZEF Working Paper No. 53, Center for Development Research. University of Bonn, Bonn

[9] Waibel, G. (2010): State Management in Transition: Understanding Water Resources Management in Vietnam. ZEF Working Paper No. 55, Center for Development Research. University of Bonn 


\section{Annexes}

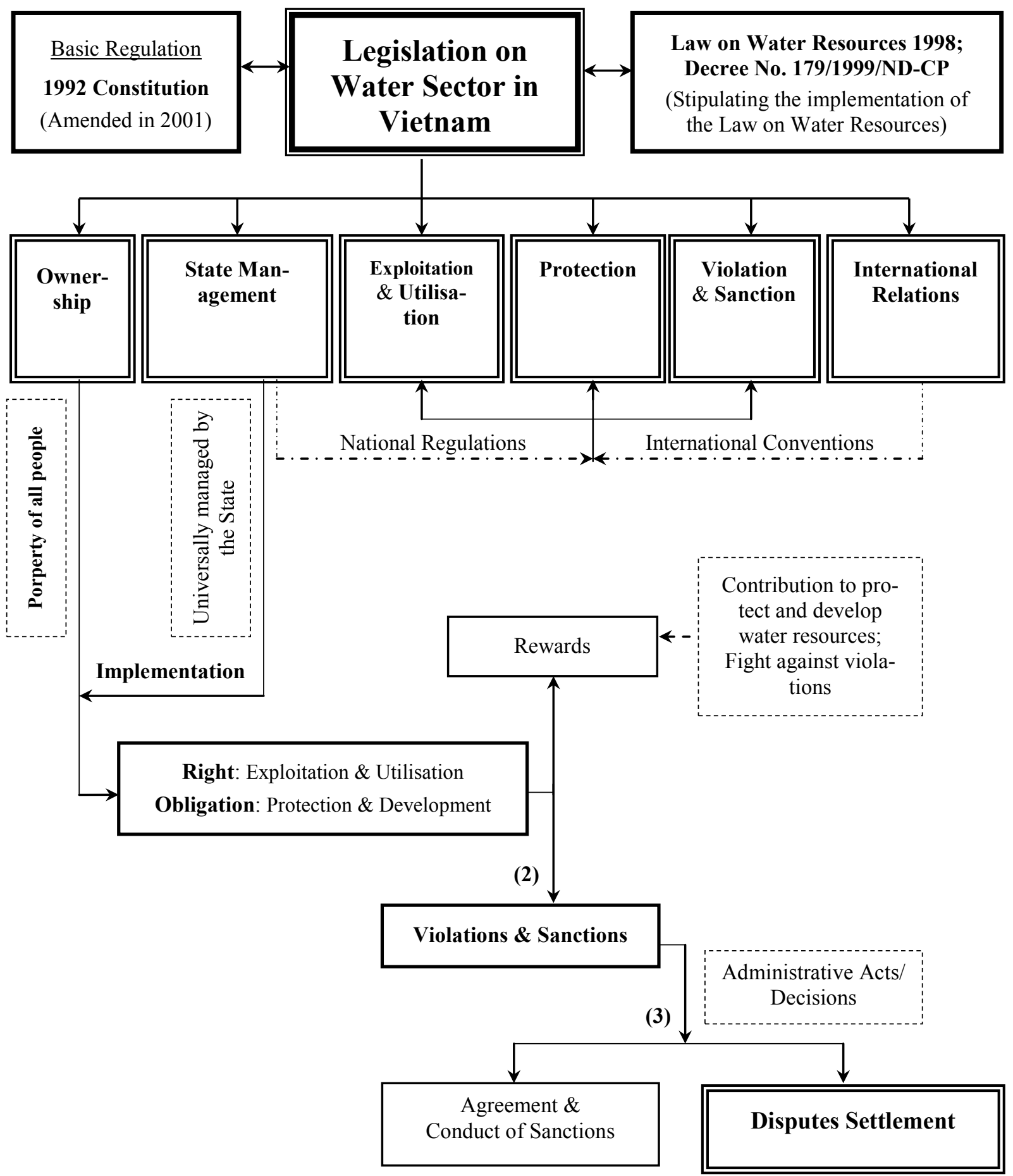

Chart 1. Position and key dimensions of water sector legislation in Vietnam 


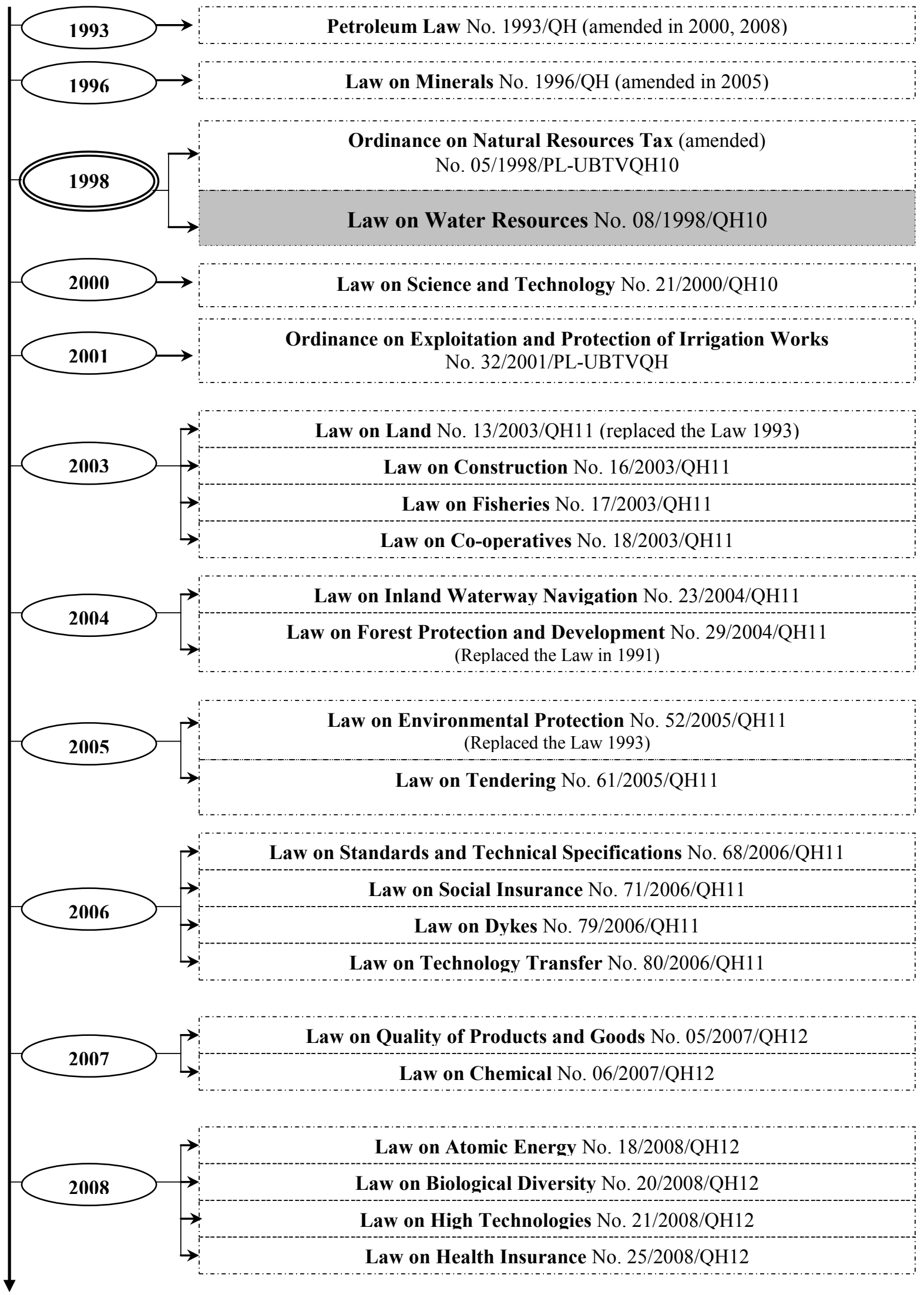

Chart 2. Key laws, ordinances on water resources protection 


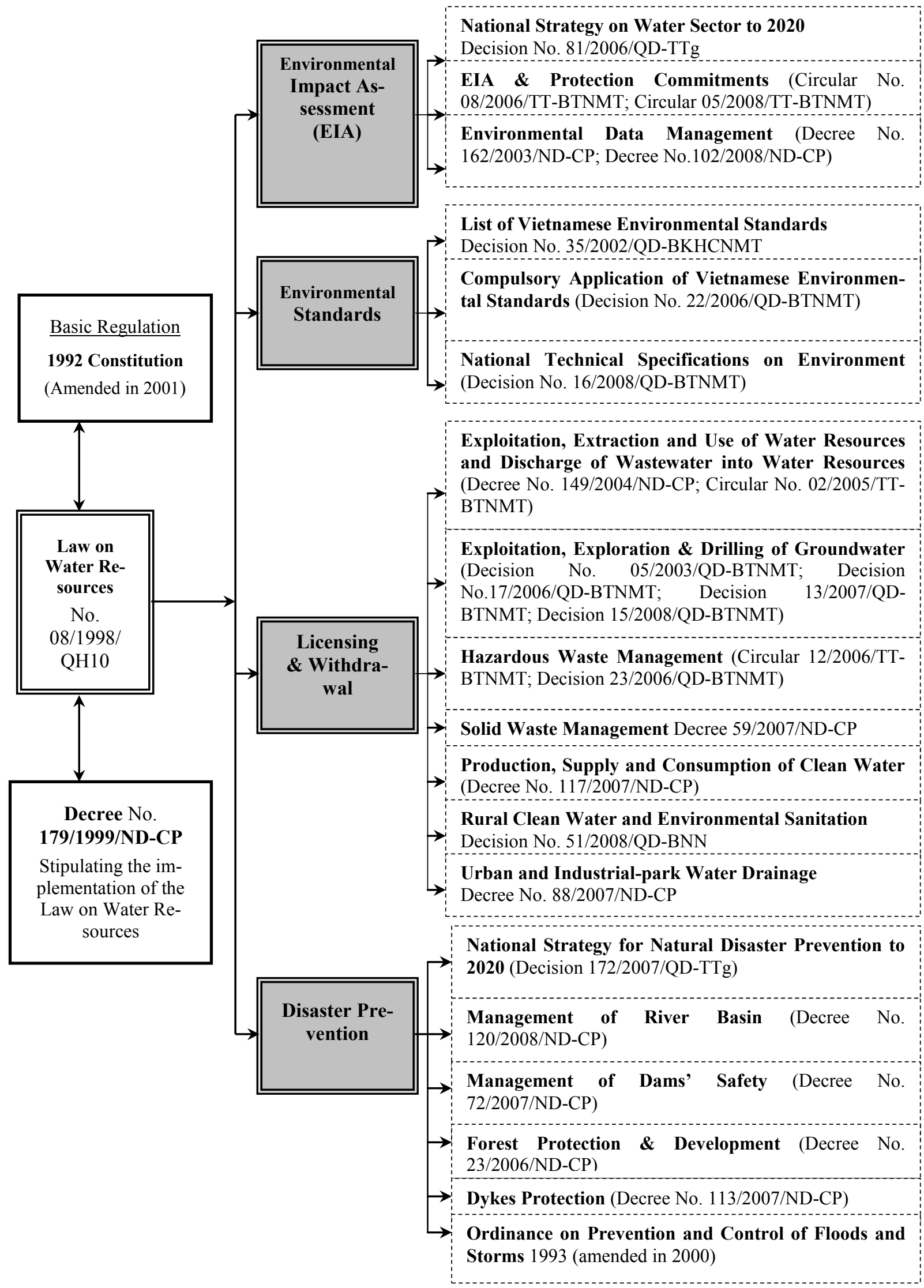

Chart 3. Key regulations on water resources protection 


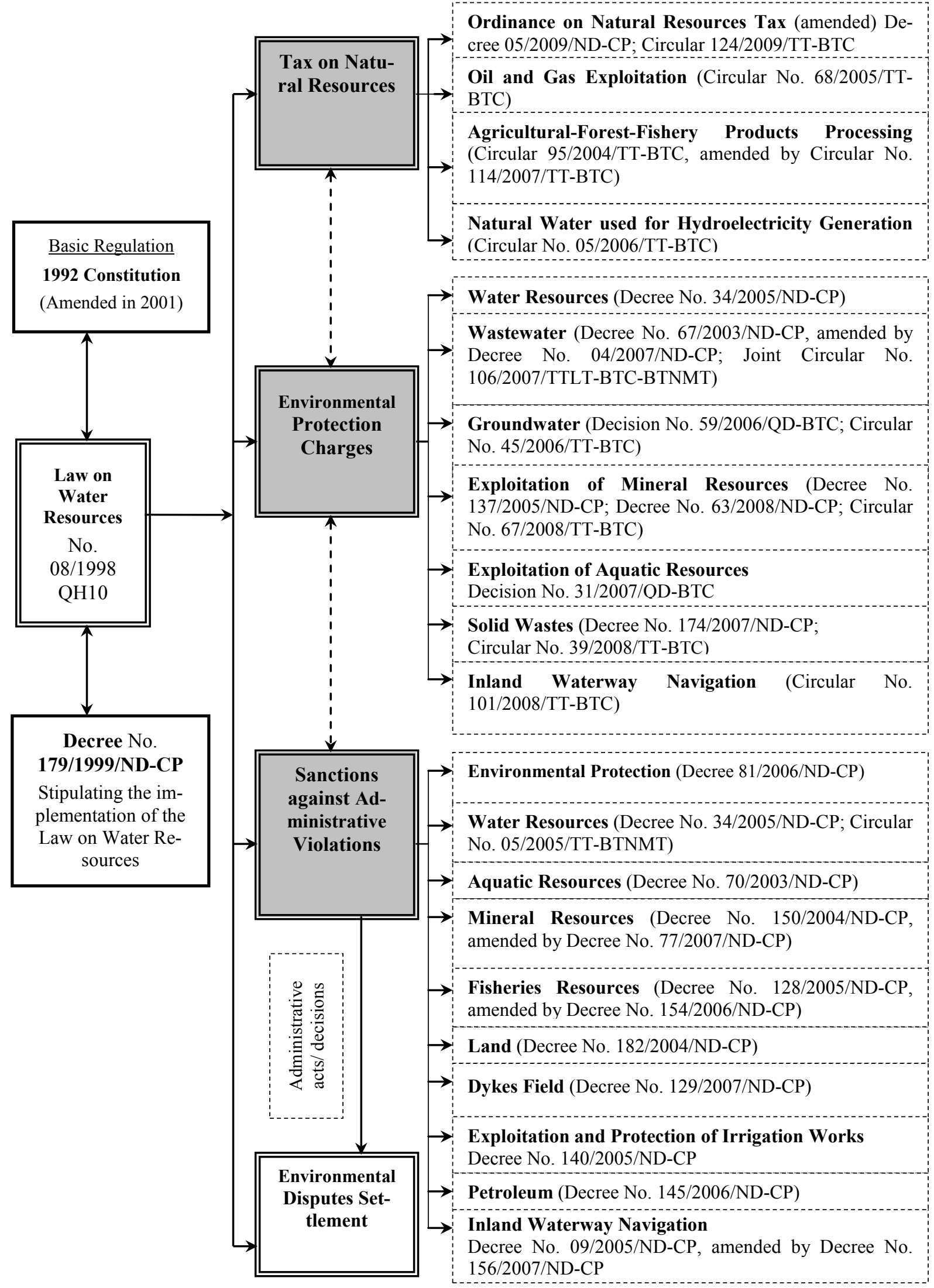

Chart 4. Key regulations on violations and sanctions 


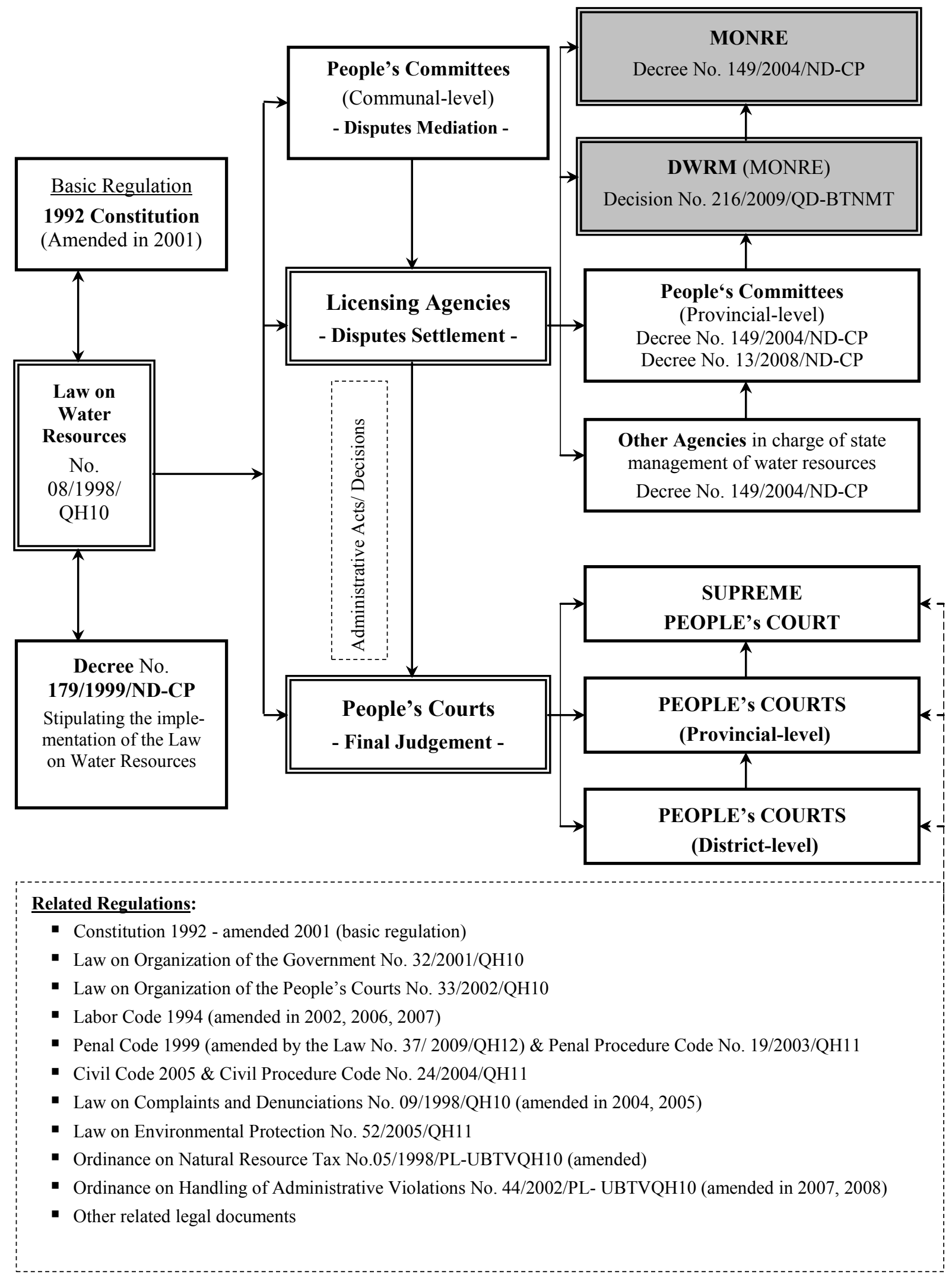

Chart 5. Dispute settlement system in environmental fields 


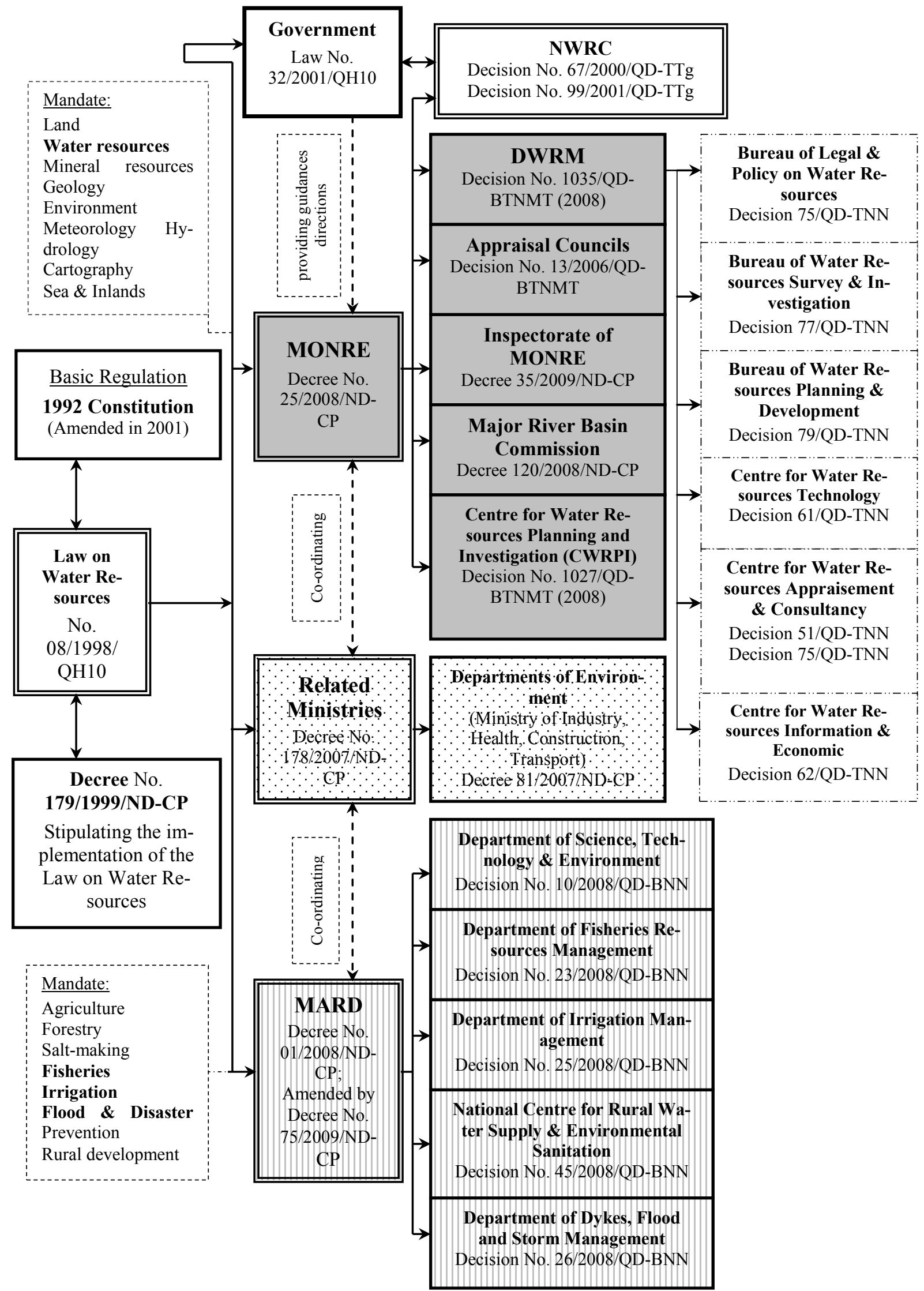

Chart 6. State management on water sector at national level 




Chart 7. State management on water sector at local levels 


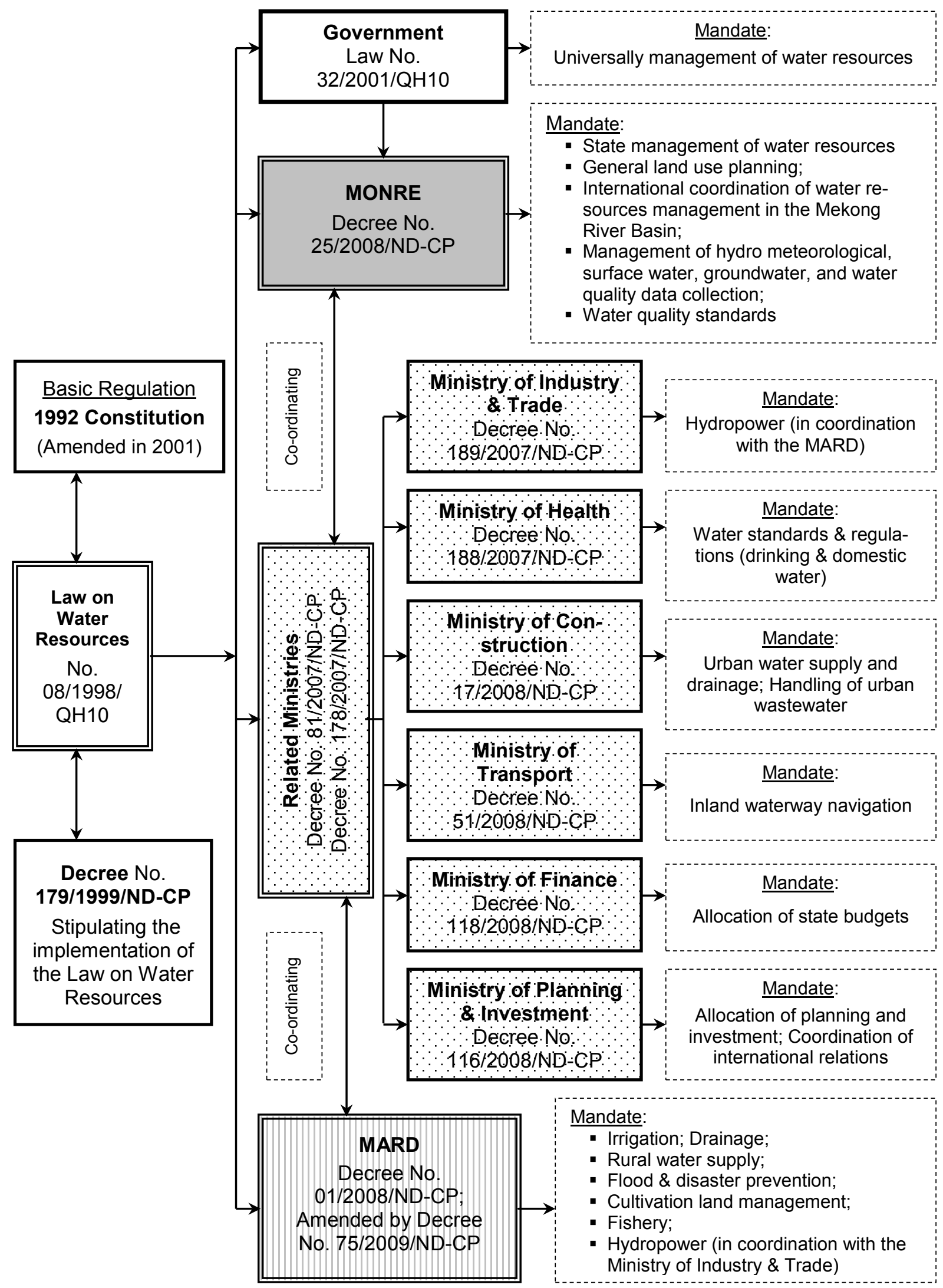

Chart 8. Delivery of state responsibilities for water resources management 